\title{
Measures Development to Improve Expenditure Efficiency of Social Services Public Iinstitutions in Volgograd Oblast
}

\author{
Svetlana Solodova \\ Volgograd State University, \\ Institute of Economics and Finance \\ Department of accounting and economic security \\ Volgograd, Russia \\ ipa70@mail.ru
}

\author{
Natalya Dolidze \\ International Institute of Law \\ Department of criminal and law disciplines \\ Volzhskiy, Volgograd Oblast, Russia \\ anchutka@mail.ru
}

\author{
Natalya Kulikova \\ Volgograd State University, \\ Institute of Economics and Finance \\ Department of accounting and economic security \\ Volgograd, Russia \\ kulikovanata72@yandex.ru
}

\begin{abstract}
The paper examines the issue of the budget allocation system efficiency. The article presents the project of budget expenditure optimization by establishing the relationship between the size of the allocated target funds and the impact of the results of achieving public services quality. The authors have conducted the analysis of changes in funding social services public institutions of Volgograd Oblast. As a typical example, the activity indicators of the "Volga social rehabilitation center for minors" are given. The proposed measures to optimize the structure of budget expenditures are intended to influence the process of overcoming the uneven development of the economy public sector in Volgograd Oblast.
\end{abstract}

Keywords - uneven economy development, expenditure authorization system, public institution, social sphere, expediency of using funds, multivariate estimates

\section{INTRODUCTION}

The positive trends in Russia's economy are undoubted. Macroeconomic indicators are rising, GDP is growing, and inflation is at a record low. On the other hand, the leading economists of the country do not deny that real incomes of Russians do not increase, but rather tend to decrease [1].

The current situation in the country calls for thinking not only about the fact of development itself, but also about its qualitative characteristics, about cause-and-effect relations existing between the determining funding volumes procedure and the results of spending the funds received.

"In the context of Russia's accession to the WTO and the application of economic sanctions against our country by the EU countries, the main task is to ensure economic security and stability of socio-economic development of the Russian Federation" [2].

This study is aimed at developing measures to improve the effectiveness of social services public institutions costs in Volgograd Oblast on the basis of the analysis of changes in funding volumes.

\section{MATERIALS AND METHODS (MODEL)}

A fairly effective system of authorizing budget expenditures has formed since the budget reform process concept was implemented in the Russian Federation in 20042006. "A priori, the importance of multiple procedures for authorizing budget expenditures ultimately determines the results of the targeted budget funds" [3]. The application of expenditure authorization accounts makes it possible to track the expenditure of funds allocated from the budget to chief managers, managers, recipients of budget funds, as well as to budgetary and autonomous institutions. The current accounting system allows to track at what stage of spending this or that amount of budgetary obligations limits or provisions is now.

The targeted spending in budget accounting is provided by the use of expenditure type codes in the budget classification together with the operation codes of the federal government sector.

The application of the 44-FZ Law "On the contract system in goods, works, and services procurement for federal and municipal needs" ensures the acquisition of necessary goods, works, and services at minimum prices. One of the latest changes in the budget accounting put into effect in 2017 
allows to determine the amount of funds that was saved as a result of contracts signed on the bidding basis.

Such a situation suggests the possibility of the problem focusing not only in funds development, but also in their distribution. The analysis of the national economic situation shows the existence of certain contradictions between the expenses size and the expenditure effect.

An example of means distribution in social service public institutions of Volgograd Oblast is indicative from the point of view of financing amounts initial distribution by the directions of use (types of expenses).

Studying the trends in funding volume changes we considered financial-economic indicators of the following state-funded social service institutions in Volgograd Oblast: State-funded specialized institution of social service (SFSI SC) Trust Volgograd Oblast rehabilitation center for children with disabilities; SFSI SC Krasnoarmeisky social rehabilitation center (SRC) for minors; SFSI SC Volzhskiy SRC for minors; SFSI SC Bykovsky SRC for minors; and SFSI SC Kamyshinskiy SRC.

The analysis of financing indicators is carried out on the example of SFSI SC Volzhskiy SRC for minors as a typical representative of this type of institutions. The change in funding SFSI SC Volzhskiy SRC for minors is presented in Table 1.

TABLE 1. ANALYSIS OF CHANGES IN FUNDING ON THE EXAMPLE OF SFSI SC VOLZHSKIY SRC FOR MINORS

\begin{tabular}{|l|c|c|c|c|}
\hline \multirow{2}{*}{ Name of indicator } & \multicolumn{3}{|c|}{ Value of indicator } \\
\cline { 2 - 5 } & $\begin{array}{c}\text { Fact, } \\
\text { 2017, } \\
\text { thousand } \\
\text { rubles } \\
\text { [4] }\end{array}$ & $\begin{array}{c}\text { Plan (for } \\
\text { the set of } \\
\text { targeted } \\
\text { items), } \\
\mathbf{2 0 1 8} \\
\text { thousand } \\
\text { rubles } \\
\text { [5] }\end{array}$ & $\begin{array}{c}\text { Deviation, } \\
\text { thousand } \\
\text { rubles }\end{array}$ & $\begin{array}{c}\text { Growth } \\
\text { rate, \% }\end{array}$ \\
\hline $\begin{array}{l}\text { Total expenses } \\
\text { including }\end{array}$ & 35211 & 39572 & +4361 & 112,4 \\
\hline $\begin{array}{l}\text { Remuneration of labour } \\
\text { and indirect labour charges }\end{array}$ & 24679 & 28919 & +4240 & 117,2 \\
\hline communication service & 116 & 159 & +43 & 137,1 \\
\hline public utility services & 1678 & 2139 & +461 & 127,5 \\
\hline $\begin{array}{l}\text { works, services for } \\
\text { property maintenance }\end{array}$ & 997 & 1087 & +90 & 109,0 \\
\hline other works, services & 5145 & 6199 & +1054 & 120,5 \\
\hline $\begin{array}{l}\text { tangible and intangible } \\
\text { assets depreciation }\end{array}$ & 360 & - & - & - \\
\hline $\begin{array}{l}\text { tangible stocks expenses / } \\
\text { tangible stocks value } \\
\text { increase }\end{array}$ & 1043 & 459 & -584 & 44,0 \\
\hline \begin{tabular}{l} 
Other expenses \\
\hline
\end{tabular} & 1193 & 610 & -583 & 51,1 \\
\hline
\end{tabular}

In 2018, the essential increase in financing amounts almost in all directions (types) of expenses is planned in the Volzhskiy institution. The estimated growth rate of financing volumes on the absolute majority of items in relation to the actual expenses exceeds the current official inflation rates presented in Table 2. It demonstrates the real increase in funds assumed to be used in the current year in the institution.

TABLE 2. INFLATION RATES IN RUSSIA IN 2016 - 2018 [6]

\begin{tabular}{|l|c|}
\hline \multicolumn{1}{|c|}{ Period } & Inflation rate $\mathbf{( \% )}$ \\
\hline 2016 & 5,40 \\
\hline 2017 & 2,52 \\
\hline March 2017 - February 2018 & 2,20 \\
\hline January 2018 - February 2018 & 0,84 \\
\hline
\end{tabular}

Only two items will suffer the decrease in financing sums: tangible stocks expenses and other expenses.

IThe changes analysis allows to come to the conclusion that the increase in financing the main types of expenses is a compulsory measure. Thus, the increase in the Remuneration of labour and indirect labour charges item is connected with implementation of the Decree of the President of the Russian Federation of May 07, 2012 N 597 "On actions for state social policy realization". In pursuance of this Decree, the Volgograd Oblast Government has approved the measures plan ("road map") - "The Increase in efficiency and quality of the Volgograd Oblast population social services for 2013-2018". According to this document, one of its expected results in 2018 can be the increase in the average salary of social workers of social service institutions up to $100 \%$ from the average monthly wage of hired employees of other organizations, of individual entrepreneurs and natural persons (an average monthly labour income) in Volgograd Oblast" "[5]. The $17.2 \%$ increase in the Remuneration of labour and indirect labour charges item can provide the approach of the institution staff average salary to the average Volgograd Oblast key figures.

The increase in financing the expenses items of "communication services", "public utility services ", "works, services for property maintenance", and "other works, services" is connected, first of all, with the increase in prices and tariffs for the services of corresponding service organizations.

The expenses connected with the use of material stocks in the institution's activity and other expenses are cut by $56.0 \%$ and $48.9 \%$ respectively according to the itemized budget. Actually, this means that the institution will cease to buy the necessary volume of material stocks which is quite likely to affect the quality of the services provided by the institution.

In any developing economic system, there are priority directions of budget funds expenditures and "outsiders" directions financed according to the residual principle. The problems of budget funds distribution have always been and still remain rather acute. There is an opinion that introduction of resources distribution system makes sense taking into consideration the degree of subject's actual needs in receiving budgetary funds.

The solution of any problem can be sought on the basis of minimum, average or maximum consumption of funds. At the same time, the results' functional properties will not differ essentially. Speaking about this essentiality, we mean the basic changes in the objects' nature of functioning being a 
result of budget funds targeted use depending on the allocated funds volume.

When forming a budget expenditure part we should control not only funds target use, but also their expediency. The inexpediency of funds use is both the consequence and the reason of excessive financial provision of the some directions of economy public sector functioning. "It is possible to qualitatively estimate the efficiency of budget funds use applying various activity indicators capable to characterize the budget expenses efficiency" [6].

The Budgetary Code of the Russian Federation (Art. 34) defines the principle of budgetary expenses efficiency as follows: "...while preparing and implementing budgets, the participants of the budget process within the limits of the budgetary authority established for them, should proceed from the necessity to achieve the desired results with the least amount of funds (frugality) and (or) the best results using a particular budget funding (efficiency)" [7].

In fact, the principle of expenses efficiency means "the same result for smaller money" or " bigger result for the same money". Nowadays the achievement of this principle is provided by the system of government contracts following the results of state orders placement. We can discuss how much the system of state orders placement promotes increase in budgetary expenses efficiency and how much the budget saves due to its implementation. Nevertheless, today it is the only system existing in our state that allows to recognize the expenses effective.

For the last ten years, the scientific community discussions concerning the possibility of determining efficiency criteria of the budgetary expenses don't cease. Such scientists as Dr.Econ.Sci. Sukharev O.S., Dr.Econ.Sci. Tishutina O.I., PhD Econ. Afanasyev R.S., PhD Econ. Galukhin A.V., PhD Econ. Kamilov D.A. and many others have devoted their studies to this issue,

Discussing the budgetary expenses efficiency, it is necessary to realize the fact that the traditional understanding of efficiency indicators assumed the relation of one factor to another.

The modern interpretation of budget expenses efficiency does not imply the use of proportions. The lack of the usual evaluating system for the results presented in simple digital indicators, leads to the desire to somehow assess the results of the budget institution activities and to draw a conclusion about of budget expenditures effectiveness on this basis. The activities assessment could seem to provide an opportunity to draw fairly objective conclusions about costs effectiveness. However, there is a fairly substantial logical leap. Let's try to figure out what it is.

The activities of any economic entity including those operating in the economy public sector, can be evaluated through performance indicators. And we can offer quite a lot of such indicators. Another question is whether they will be sufficiently efficient to reflect the real picture of the economic entity\s activities.
The problem is a number of indicators objectively should be limited to evaluate the institution performance. Given a limited number of indicators, a formal approach to assessing the institution performance is highly likely to appear. Any stimulation of both the institution as a whole and an individual employees based on ratings results will inevitably lead to a formal approach to the achievement of the necessary indicators. And the more significant the stimulation is, the faster is the formalization process of the institution performance indicators.

Formalization of socially oriented activities cannot lead to optimization and improvement of the economy social component as a whole.

The problem is that the activities of state and municipal institutions are primarily related to the provision of socially oriented services. A sufficiently large number of social services cannot be quantified. To be more precise, the evaluation of services rendered often does not provide a measure of the funds use effectiveness. As a rule qualitative performance indicators for economic entities cannot be evaluated by numerical indicators.

In our opinion, the establishment of only some minimum indicators can be useful in relation to the socially-oriented institutions activities. Other things are very individual. And the stricter requirements are, the higher is the level of mystification which becomes truly enormous in the shortest time.

Basing on the above mentioned, we recognize that the idea of assessing budget spending effectiveness according to the certain specified criteria is not entirely rational in itself. It ensures not expenditures efficiency, but rather employees training to achieve certain performance indicators.

The directions of funds expenditure of the subject in the economy public sector are defined by the plan of financial and economic activity (FEA plan) of the institution. The FEA plan basis is the formation of the institution estimates.

Estimate formation is one of the key issues for determining the necessary expenses volume. From the position of the allocation of resources in accordance with the needs of the object, in the preparation of estimates, it is necessary to separate costs both in the directions of expenditure (by code KOSGU) and the degree of need.

In fact, forming the estimate, the budget funds recipient defines a certain desired amount which does not reflect the degree of its necessity for the entity-in-question functioning.

Our proposal is to increase the information value of the economic entity condition and determine the necessity degree of pre-planned expenditures, as well as to define the correlation between consumed resources amount and public (municipal) services quantity and quality. The criterion for determining the level of costs impact on the quantity and quality of public (municipal) services should be a direct or indirect relation of costs to services provided by the institution. Direct costs should be a priority in funds allocation. The size of indirect costs should depend on the direct costs financing indicators. 
From the point of view of budget savings and optimization of budget expenditure part, it makes sense to introduce in the budget classification code an item that determines the usefulness degree or the necessity level for the expenditure volume claimed by the recipient.

Classification of costs according to their usefulness degree for achieving goals should be taken into account while forming and executing budget estimates.

\section{III.RESULTS AND DISCUSSION}

The itemized estimate amount could potentially be identified as a progressive indicator focused on the budget recipient's maximum responsibilities.

The assignment of the of budget expenditures amount to certain processes within an institution may serve a basis for costs classification depending on their possible impact on achieving the purpose for which the institution is established.

The dependence of budgetary service quality on the allocated budget funds amount should be put at the forefront in solving the problem of sizing budget funds allocated for the achievement of the stated objectives.

The minimum amount of estimate costs can be considered as an absolutely necessary financial support for the activities of the economic entity. The maximum estimate expenses amount can be considered as an amount the increase of which will not ensure the qualitative improvement of the offered state service.

We come to the issue of the possible introduction of multivariate costs estimate into practice. Depending on the budget condition, more or less funds can be allocated to achieve the goal,. However, the allocation of a larger amount of funds should become the basis for monitoring the activities efficiency improvement.

Of course, using multivariate estimates requires certain additional labor costs, but the effect aimed at eliminating contradictions in the development of the public sector both in the Russian Federation economy as a whole, and in Volgograd Oblast in particular, will ensure a positive financial result.

\section{CONCLUSION}

The introduction of a system determining the allocated budget funds volume depending on its importance for the process of the of the economic subject goal achievement (the goal for which the subject was created) can be considered one of the directions for overcoming contradictions in the development of the Russian Federation economy and its public sector in particular.

The possibility of using multivariate estimates, as well as the development of the institution performance indicators system makes the basis for practical application of this principle.

\section{References}

[1] P. Kazarnovsky, Yu. Starostina. Real income of Russians showed a decrease for the fourth consecutive year [Real'nye dohody rossiyan pokazali snizhenie chetvertyj god podryad]. Available at: https://www.rbc.ru/economics/25/01/2018/5a69dc3b9a7947621f973468

[2] Podugolnikova M.O., Fedotova G.V. Problems of sustainable development of regions in the conditions of the current financial crisis: collection of scientific works of the 3rd international scientific and practical conference "Cluster initiatives in the formation of the progressive structure of the national economy" [Problemy ustojchivogo razvitiya regionov $\mathrm{v}$ usloviyah sovremennogo finansovogo krizisa: sbornik nauchnyh trudov 3-j Mezhdunarodnoj nauchno-prakticheskoj konferencii «Klasternye iniciativy $\mathrm{v}$ formirovanii progressivnoj struktury nacional'noj ehkonomiki»], 2017. C. 212-215.

[3] Trifonova T.S. Legal, functional, control aspects of authorization in activity of Federal Treasury / Financial Analytics: problems and solutions [Pravovoj, funkcional'nyj, kontrol'nyj aspekty sankcionirovaniya $\mathrm{v}$ deyatel'nosti federal'nogo kaznachejstva / Finansovaya analitika: problemy i resheniya], 2015. No. 6 (240). C. 5866.

[4] The 2017 report on financial results of activity of SFSI SC Volzhskiy social rehabilitation center for minors [Otchet o finansovyh rezul'tatah deyatel'nosti GKSU SO «Volzhskij social'no-reabilitacionnyj centr dlya nesovershennoletnih» za 2017 g.], (f. 0503121). Available at: http://bus.gov.ru/pub/agency/113121/annual-balances

[5] Information on budget estimates indicators (Change No. 1) of SFSI SC Volzhskiy social rehabilitation center for minors for 2018 [Informaciya o pokazatelyah byudzhetnoj smety (Izmenenie №1) GKSU SO «Volzhskij social'no-reabilitacionnyj centr dlya nesovershennoletnih» na 2018 g.]. Available at: http://bus.gov.ru/public/printform/show.html?pfid=19183993

[6] Inflation in Russia [Inflyaciya v Rossii]. Available at: http://xn---ctbjnaatncev9av3a8f8b.xn--p1ai/

[7] Action plan ("road map")"Improvement of social services efficiency and quality for the population of Volgograd Oblast in 2013 - 2018". Approved by the Decree of the Volgograd Oblast Government № 128-p dated 26.03..2013 [Plan meropriyatij ("dorozhnaya karta") "Povyshenie ehffektivnosti i kachestva uslug $\mathrm{v}$ sfere social'nogo obsluzhivaniya naseleniya Volgogradskoj oblasti na 2013 - 2018 gody". Utverzhdena postanovleniem Pravitel'stva Volgogradskoj oblasti № 128-p ot 26.03..2013 g.]Available

http://publication.pravo.gov.ru/Document/View/ 3400201609300014?index=1\&rangeSize $=1$

[8] Chibisova E.I., Chibisov O.V., Vershinina A.A. Principles of innovative model formation for the control over budgetary funds efficiency use /[ Principy formirovaniya innovacionnoj modeli kontrolya nad ehffektivnost'yu ispol'zovaniya byudzhetnyh sredstv]. Statistics and Economy. 2013. No. 6. P. 117-120.

[9] The Budgetary Code of the Russian Federation [Byudzhetnyj kodeks Rossijskoj Federacii]. Available at: http://www.consultant.ru/document/cons_doc_LAW_19702/9d0dc5bffb e52f6f95e97813e0ef420708952b4e/ 